\title{
Znaczenie i sposoby rozwoju kreatywności w gospodarce cyfrowej
}

DOI: 10.47050/65591876.176-186

Dorota Roszkowska

W gospodarce cyfrowej, w której technologie informacyjno-komunikacyjne umożliwiają niemal każdemu korzystanie z nieograniczonego źródła inspiracji dzięki wykorzystaniu zasobów internetu i sieci społecznościowych, to niestandardowy sposób używania danych i informacji decyduje o uzyskiwanych przewagach konkurencyjnych i innowacyjnych. Z tego względu wśród kompetencji cyfrowych kreatywność ma szczególne znaczenie. Adaptacja narzędzi cyfrowych już na etapie edukacji może pozwolić na zwiększenie wydajności i satysfakcji z wykonywanej pracy przyszłych pracowników. Rozdział przedstawia przykładowe narzędzia cyfrowe, które mogą być inspiracją do wdrożenia nowych sposobów rozwoju kreatywności u uczniów, a także w środowisku pracy.

\section{Słowa kluczowe:}

gospodarka cyfrowa

kompetencje cyfrowe

kreatywność 


\section{Importance and ways of developing creativity in the digital economy}

DOI: $10.47050 / 65591876.176-186$

Dorota Roszkowska

In the digital economy, where information and communication technologies enable almost everyone to use an unlimited source of inspiration, through the use of Internet resources and social networks, the non-standard way of using data and information determines the competitive and innovative advantages. For this reason, creativity is of particular importance among the catalog of digital competences. Adaptation of digital tools already at the stage of education, may allow to increase the efficiency and satisfaction of the work of future employees. The publication contains a description of examples of digital tools that can be an inspiration to implement new ways of developing creativity among students, as well as in the work environment.

\section{Keywords:}

digital economy

digital skills

creativity 


\section{Wprowadzenie}

Ideacja, którą można też określić jako etap kreacji, stanowi pierwszy element procesu innowacyjnego. Przełomowe innowacje nie powstają bez twórczego, nieschematycznego myślenia i działania. Można zatem stwierdzić, że nie ma innowacji bez kreacji, a kreacji bez kreatywności. Kreatywność to przykład kompetencji przyszłości, która w gospodarce cyfrowej stanowi kluczową przewagę konkurencyjną. Można stwierdzić, że jest paliwem innowacyjności, która stanowi główny czynnik współczesnego wzrostu gospodarczego. Kreatywność można rozwijać i stymulować. Pobudzanie kreatywności z wykorzystaniem odpowiednich technik może pozytywnie wpłynąć na działania innowacyjne.

W gospodarce cyfrowej, w której technologie informacyjno-komunikacyjne umożliwiają niemal każdemu korzystanie z nieograniczonego źródła inspiracji poprzez wykorzystanie zasobów internetu i sieci społecznościowych, to właśnie niestandardowy sposób korzystania z danych i informacji decyduje o uzyskiwanych przewagach konkurencyjnych i innowacyjnych. Wzrost zaawansowania procesów automatyzacji i robotyzacji sprawia, że wykonanie powtarzalnych czynności wymaga coraz mniejszego zaangażowania człowieka. Sztuczna inteligencja i uczenie maszynowe wpływają w znacznym stopniu na strukturę rynku pracy i kompetencji poszukiwanych u pracowników. Wymusza to także zmiany w programach kształcenia instytucji edukacyjnych, które za pomocą analizy zachodzących trendów społecznych, gospodarczych i technologicznych, a także ścisłej współpracy z pracodawcami powinny dostosowywać swoją ofertę edukacyjną do wyzwań pracowników przyszłości. Wydaje się, że aktualny stan oferty kształcenia instytucji edukacyjnych w większości nie nadąża za potrzebami rynku. Duża liczba dostępnych na rynku odpłatnych kursów i szkół prywatnych, oferujących szkolenia z zakresu kompetencji cyfrowych, kodowania, robotyki etc., pokazuje, że oferta edukacyjna publicznych instytucji edukacyjnych jest mało elastyczna. Warto także zauważyć, że gospodarka cyfrowa $z$ jednej strony zmienia strukturę popytu na kompetencje pracowników, z drugiej udostępnia narzędzia, dzięki którym nabycie nowych kompetencji może stać się łatwiejsze. Narzędzia cyfrowe pozwalają na zwiększenie efektywności przyswajania nowych kompetencji, co $w$ dobie dynamicznych zmian na rynku pracy ma duże znaczenie.

Niniejszy rozdział ma na celu określenie znaczenia kreatywności w gospodarce cyfrowej i katalogu kompetencji cyfrowych. Zostaną 
w nim także przedstawione przykłady narzędzi cyfrowych, które mogą stanowić inspirację do wdrożenia nowych sposobów rozwoju kreatywności wśród uczniów, a także w środowisku pracy.

Rola kreatywności w gospodarce cyfrowej. Wyzwania kompetencyjne

Rewolucja technologiczna napędzana rozwojem technologii informacyjno-komunikacyjnych wpłynęła na zmianę paradygmatu funkcjonowania gospodarki, tworząc nowe reguły gry rynkowej. Istotnie zmieniły się warunki funkcjonowania przedsiębiorstw, rynku pracy i edukacji. Początek wyżej wymienionych zmian dało się zauważyć już pod koniec lat 80., kiedy to mogliśmy mówić o początku rewolucji informatycznej, objawiającej się spadkiem gospodarczego znaczenia zasobów surowcowych i wzrostem znaczenia informacji, wiedzy i intelektu, stanowiących kluczowe zasoby tzw. nowej gospodarki. W takich warunkach gospodarczych technologie umożliwiające efektywne generowanie, przetwarzanie i transfer danych i informacji stały się nowym paliwem wzrostu. Nastąpiły też zmiany struktury popytu na kompetencje pracowników. Efektywność, innowacyjność i konkurencyjność sektora przemysłu, przechodzącego dzięki zastosowaniu technologii cyfrowych tzw. czwartą rewolucję przemysłową, a także każdego innego obszaru gospodarki, warunkowane są odpowiednimi kompetencjami pracowników, którzy będę potrafili wykorzystać nowe możliwości. Charakterystyczne dla gospodarki cyfrowej poza informatyzacją i cyfryzacją jest kluczowe znaczenie internetu, dostęp do zasobów sieciowych i umiejętność twórczego opracowywania nowych rozwiązań i produktów oraz budowania sieci kontaktów. Potwierdzają to sukcesy firm opierających swój model działania na zasadach tzw. ekonomii dostępu i współdzielenia (sharing economy). W dobie transformacji cyfrowej to kompetencje cyfrowe pracowników będą decydować o sukcesie przedsiębiorstw i gospodarek. Skuteczna transformacja cyfrowa gospodarki nie jest możliwa bez nowoczesnego i efektywnego systemu edukacji i szkolnictwa, kształcących kreatywnych pracowników potrafiących skutecznie wykorzystać nowe technologie i adaptować się do szybko zmieniającego się otoczenia gospodarczego i społecznego.

Uwzględniając aktualne warunki i możliwości tworzenia nowych rozwiązań, można wysunąć tezę, że w erze cyfrowej kreatywność staje się kluczowym czynnikiem przewag konkurencyjnych. Wzrasta też zna- 
czenie zewnętrznych (znajdujących się poza przedsiębiorstwem) źródeł wiedzy, technologii, innowacji, a także zdolności firm do integrowania, dalszego rozwijania i szybkiego wdrażania innowacyjnych rozwiązań w dużej skali. Źródłem kreatywności i innowacyjności w gospodarce i społeczeństwie są działania ludzi uwarunkowane ich potencjałem twórczym oraz czynnikami technologicznymi, ekonomicznymi i socjologicznymi (Zorska, Molęda-Zdziech, Jung 2014, s. 3-24). John Howkins zauważył, że kreatywność sama w sobie nie jest dobrem w kategoriach ekonomicznych, ale jej produkty mogą nim być (Howkins 2014). Produktem kreatywności jest innowacja, która ma już wymierną wartość ekonomiczną. Choć pomysł i wdrożenie rynkowe dzieli bardzo duża luka, to bez fazy koncepcyjnej nie może nastąpić rozwój produktu i jego finalne wdrożenie. Stwierdzić zatem można, że gospodarka cyfrowa kształtuje popyt na kompetencje cyfrowe, które zgodnie z prognozami będą stanowiły o umiejętności odnalezienia się pracowników i obywateli w nowym otoczeniu gospodarczym.

\section{Kompetencje w erze cyfrowej. Rola kreatywności}

Termin „umiejętności i kompetencje cyfrowe" jest bardzo szeroki i trudny do precyzyjnego określenia. Jednoznaczne wskazanie katalogu kompetencji cyfrowych budzi spory i wątpliwości (Meyers, Erickson, Small 2001; Prensky 2001). Organizacje międzynarodowe oraz instytuty badawcze i społeczne podejmują próby stworzenia tzw. ram kompetencji cyfrowych (Cachia, Ferrari, Ala-Mutka, Punie 2010). Opracowują m.in. katalogi kompetencji cyfrowych obywateli, kompetencji cyfrowych konsumentów, kompetencji cyfrowych w zakresie przedsiębiorczości. Badania Wspólnego Centrum Badawczego Komisji Europejskiej (European Commission Joint Research Centre - JRC) w obszarze badania kompetencji cyfrowych rozpoczęły się w 2005 r. i koncentrują się na określeniu optymalnego sposobu wykorzystania technologii informacyjno-komunikacyjnych w procesie uczenia, w tym szczególnie nabywania nowych kompetencji i umiejętności. Badania JRC w latach 2016-2017 opierały się na trzech głównych aspektach, tj. umiejętnościach i kompetencjach XXI w., innowacji i modernizacji systemu edukacji i szkolenia oraz rozwoju tzw. otwartej edukacji (Learning and Skills...).

JRC jako umiejętności i kompetencje XXI w. wskazało kreatywność, przedsiębiorczość, umiejętność uczenia się. Raport DIGCOMP, poświęcony opracowaniu tzw. ram rozwoju i zrozumienia kompetencji cyfro- 
wych w Europie, przygotowany przez JRC (Ferrari 2013, s. 4-5) jako główne obszary kompetencji cyfrowych wymienia:

$\rightarrow$ Informacje: identyfikowanie, lokalizowanie, pobieranie, przechowywanie, organizowanie i analizowanie informacji cyfrowych przy równoczesnej ocenie ich przydatności i celu.

$\rightarrow$ Komunikacja: komunikowanie w środowisku cyfrowym, udostępnianie zasobów za pomocą narzędzi online, łączenie się z innymi i współpraca za pomocą narzędzi cyfrowych, interakcja i uczestnictwo w społecznościach i sieciach, świadomość międzykulturowa.

$\rightarrow$ Tworzenie treści: tworzenie i edytowanie nowych treści (od przetwarzania tekstu do obrazów i wideo); integrowanie i ponowne opracowywanie wcześniejszej wiedzy i treści; tworzenie i twórcze wyrażenie, produkty medialne i programowanie; zajmowanie się prawem własności intelektualnej i licencji oraz ich zastosowanie.

$\rightarrow$ Bezpieczeństwo: ochrona osobista, ochrona danych, ochrona tożsamości cyfrowej, środki bezpieczeństwa, bezpieczne i zrównoważone użytkowanie.

$\rightarrow$ Rozwiązywanie problemów: identyfikacja cyfrowych potrzeb i zasobów, podejmowanie świadomych decyzji co do tego, które narzędzia cyfrowe są najbardziej odpowiednie w zależności od celu lub potrzeby, rozwiązywanie problemów pojęciowych za pomocą środków cyfrowych, kreatywne wykorzystywanie technologii, rozwiązywanie problemów technicznych, rozwijanie kompetencji własnych i pomoc w rozwijaniu kompetencji innych.

W zakresie tworzenia treści, gdzie kreatywność odgrywa istotną rolę, raport wskazuje na znaczenie takich umiejętności jak:

$\rightarrow$ Opracowywanie treści, tj. tworzenie treści w różnych formatach, w tym multimedialnych, oraz ich edycja i ulepszanie; także tych, które powstały wcześniej lub zostały stworzone przez innych (w celu twórczego wyrażania się za pomocą cyfrowych mediów i technologii).

$\rightarrow$ Integracja i ponowne opracowanie (w celu zmodyfikowania, udoskonalenia i połączenia istniejących zasobów w celu stworzenia nowej, oryginalnej i odpowiedniej treści i wiedzy).

$\rightarrow$ Prawa autorskie i licencje (w celu zrozumienia, w jaki sposób prawa autorskie i licencje mają zastosowanie do informacji i treści). 
$\rightarrow$ Programowanie (w celu zastosowania ustawienia, modyfikacji programu, aplikacji programowych oraz zrozumienia zasad programowania).

W badaniach Sue Cranmer (2014, s. 165-177) przedstawiono podobny katalog kluczowych kompetencji cyfrowych. W większości analiz w zakresie kompetencji cyfrowych kreatywność identyfikowana jest jako istotna umiejętność, umożliwiająca przede wszystkim tworzenie treści, a następnie ich przetwarzanie, z wykorzystaniem narzędzi informatycznych i cyfrowych. Kreatywność pozwala na tworzenie produktów, w tym produktów cyfrowych, z wykorzystaniem narzędzi technologicznych, stanowiących w gospodarce cyfrowej główne narzędzia pracy. Nowe technologie, aby mogły zostać efektywnie wykorzystane, wymagają zastosowania procesu twórczego myślenia. W kontekście katalogu kompetencji cyfrowych tworzenie treści należy uznać za jedną z najważniejszych kompetencji cyfrowych, przede wszystkim ze względu na to, że generuje największą wartość dodaną. Kompetencje w obszarze wykorzystywania technologii informacyjno-telekomunikacyjnych wskazywane są jako istotne szczególnie z perspektywy edukacji i zarządzania (Passey, Tatnall 2014, s. 165-177). Narzędzia te muszą stać się podstawą systemu edukacji w zakresie technologii cyfrowych.

\section{Kreatywność jako kluczowa kompetencja ery cyfrowej. Bariery i czynniki rozwoju kreatywności}

Kreatywność można zdefiniować jako umiejętność tworzenia nowych pomysłów. Zależy ona od wielu czynników - przede wszystkim od wiedzy i doświadczenia, stanowiących "pulę" zasobów, które możemy wykorzystać w procesie twórczym, oraz od motywacji i ambicji, pozwalających podjąć trud tworzenia nowych kombinacji na podstawie znanych faktów. Nie bez znaczenia pozostają intuicja i otwartość, a także pewność siebie, które wpływają na ograniczenie wewnętrznej krytyki w procesie generowania nowych pomysłów. Pewne cechy osobowościowe ograniczają kreatywność, a inne, jak gotowość do ryzyka, elastyczność, ją wzmacniają. W gospodarce cyfrowej, a jednocześnie gospodarce obfitości zasobów wiedzy i dostępu do nich, to właśnie umiejętność tworzenia nowych kombinacji z istniejących danych decyduje o przewagach rynkowych. Co więcej, cyfryzacja wpływa też na wzrost znaczenia sektora kreatywnego, na który składają się m.in. reklama, architektura, 
dzieła sztuki, rzemiosło artystyczne, wzornictwo i projektowanie mody, wideo, film, działalność muzyczna i fotografia, działalność artystyczna, ale także działalność w zakresie oprogramowania.

Richard Florida (2002) uważa, że najlepiej rozwijające się ośrodki miejskie to te z najsilniejszą tzw. klasą kreatywną. Według niego istnieją trzy siły działające pozytywnie na miasta, tj. technologia, talent i tolerancja. Miejsca tolerancyjne, otwarte, o różnorodnej strukturze demograficznej i przyjazne przyciągają kreatywne jednostki. Oznacza to, że rozwój takich kompetencji miękkich jak: tolerancja, otwartość, autentyczność, stanowi ważny element rozwoju kreatywności.

Innowacyjność, rozumiana jako proces wdrażania rynkowego nowych pomysłów, nie ma charakteru liniowego. Poszukiwanie nowych, możliwych do wdrożenia pomysłów ma z punktu widzenia przedsiębiorstwa charakter gry zespołowej. Ważną rolę w rozwoju kreatywności odgrywa zatem kultura organizacyjna, m.in. zachęcająca do konstruktywnej krytyki. Ma to umożliwić spojrzenie na dany pomysł z różnych perspektyw. Należy też zauważyć, że zróżnicowane, interdyscyplinarne zespoły są z reguły bardziej efektywne niż zespoły homogeniczne. Kreatywność cechuje się procesowością i etapowością, wymaga współpracy zespołu ludzi, godzenia interesów różnych stron. Kreatywność zaczyna być postrzegana jako kompetencja, którą można i należy zarządzać systemowo. Złożona teoria kreatywności wskazuje bowiem, że kreatywność nie składa się z talentów jednostek, ale zależy od umiejętności zarządzania tym procesem na poziomie zbiorowym, w tym od optymalnego zarządzania relacjami i zasobami wewnątrz określonej grupy czy struktury (Kasza 2014, s. 49). Brak systemowego podejścia do kreatywności i rozwoju systemu sprzyjającego jej rozwojowi sprawia, że w praktyce większość firm nie jest gotowa zmierzyć się z problematyką kreatywności. Dotyczy to głównie indywidualnego pracownika, którego kreatywny potencjał zwykle nie jest w pełni wykorzystany. Większość przełożonych mimo deklaracji nadal bardziej ceni zręcznych wykonawców poleceń, sprawnych, ale niezbyt twórczych rzemieślników (Kasza 2014, s. 48). Podobnie jest w szkołach i na uczelniach wyższych. W odróżnieniu od przedsiębiorstw, jednostki edukacyjne, bez realnych zagrożeń finansowych, mogłyby w dość prosty sposób wprowadzać nowe praktyki i standardy, kształtując nowe pokolenie pracowników potrafiących odnaleźć się w kulturze otwartości i kreatywności. Powyższe wskazuje, że narzędzia rozwoju kreatywności 
powinny być postrzegane szeroko, nie tylko jako techniki kreatywności, ale rozwój umiejętności miękkich i zarządczych w zakresie tworzenia otoczenia sprzyjającego kreatywności.

\section{Cyfrowe narzędzia wsparcia kreatywności}

Narzędzia cyfrowe mogą skutecznie wspomagać rozwój kreatywności i dzięki temu stanowić wartość dodaną w otoczeniu edukacyjnym. Są one dla nauczycieli istotnym wsparciem w procesie rozwoju kreatywności. Narzędzia cyfrowe rozumieć należy jako oparte na zastosowaniu technologii informacyjno-komunikacyjnych. To przede wszystkim oprogramowanie $w$ formie aplikacji, stanowiące jedno $z$ narzędzi do wykorzystania w procesie edukacyjnym, nabywania kompetencji, wykazujące liczne przewagi w stosunku do tradycyjnych metod. Narzędzia te będą spełniać swoją rolę, jeśli umożliwią rozwój innowacyjności, interdyscyplinarnego podejścia i tworzenie własnych kreatywnych rozwiązań.

Narzędzia cyfrowe mogą być także wykorzystywane jako wsparcie dla narzędzi rozwoju kreatywności, spośród których można wymienić mind mapping, TRIZ czy burze mózgów, a także popularną metodę Design thinking. Każda z nich może być wsparta narzędziami cyfrowymi. Badania naukowe sugerują, że korzystające $z$ technologii cyfrowych techniki mapowania pojęć zwiększają szybkość uczenia się (Riley, Ahlberg 2004). Narzędzia wsparcia procesów kreatywnych możemy podzielić na: narzędzia dywergencji (divergence tools), przeznaczone do generowania maksymalnej liczby niepokrywających się ze sobą pomysłów, oraz narzędzia konwergencji (convergence tools), które służą analizie, filtrowaniu i łączeniu pomysłów/idei w celu wyboru najlepszych. Różne grupy narzędzi wykorzystywane są w różnych fazach procesu innowacyjnego i mają różne cele.

Andrew Field (2015), ekspert Cambridge Education International Centre [Centrum Oceny Edukacji Międzynarodowej] Uniwersytetu w Cambridge, wymienia narzędzia cyfrowe, które mogą skutecznie pobudzać kreatywność w procesie edukacji. Są to:

$\rightarrow$ Socrative, socrative.com

Socrative to prosta w obsłudze aplikacja do tworzenia quizów, ankiet i opinii. Można jej użyć do przeprowadzenia quizu podczas lekcji, uczniowie rozwiązują zadania w czasie rzeczywistym na swoich urządzeniach mobilnych. Aplikacja umożliwia automatyczną ocenę wykonanych zadań i śledzenie postępów 
uczniów. Uczniowie mogą tworzyć własne treści (quizy, zadania) i udostępniać je wybranej grupie osób. Mogą też zbierać opinie na temat swoich prac, dzielić się swoimi propozycjami z resztą klasy. Narzędzie ma na celu przede wszystkim umożliwienie skutecznego procesu współpracy i wymiany pomysłów.

$\rightarrow$ Classtools.net, classtools.net Classtools.net to kolekcja narzędzi online pobudzających kreatywność, pozwalających każdemu tworzyć własne opracowania edukacyjne w szybki i intuicyjny sposób, z wykorzystaniem dostępnych, łatwo modyfikowanych szablonów online. Aplikacja udostępnia ponad 40 darmowych narzędzi i dodatków. Jednym z najlepszych przykładów jest Fakebook, za pomocą którego uczniowie mogą zbudować własną stronę podobną do Facebooka dla postaci historycznej lub tematu, którego się uczą. Mogą np. tworzyć profile śledzące wpływ ważnego wydarzenia, refleksje na temat debaty politycznej lub strumień kreatywności, który doprowadził do powstania muzycznego arcydzieła.

$\rightarrow$ Kahoot, kahoot.it

Kahoot pozwala każdemu tworzyć własne quizy do przeprowadzania konkursów na forum klasy. Członkowie grupy, do której skierowany jest quiz, odpowiadają za pomocą dowolnego urządzenia $z$ dostępem do sieci internetowej. Jedną z funkcji aplikacji jest wyświetlanie wyników quizów w czasie rzeczywistym. Uczniowie mają też możliwość tworzenia własnych konkursów, projektowania własnego systemu oceny i docelowo przejmują odpowiedzialność za proces uczenia.

\section{Podsumowanie}

W katalogu kompetencji cyfrowych szczególnego znaczenia nabiera kreatywność, mająca zastosowanie we wszystkich sferach życia i stanowiąca główny napęd gospodarki kreatywnej, opartej na innowacjach. Gospodarka cyfrowa daje szerokie instrumentarium, by przyswojenie nowych kompetencji było jak najbardziej efektywne. Adaptacja narzędzi cyfrowych już na etapie edukacji pozwoli na zwiększenie wydajności i satysfakcji z wykonywanej pracy przyszłych pracowników. Nowe narzędzia cyfrowe, tj. aplikacje wspomagające edukację i tworzenie treści, pojawiają się w bardzo szybkim tempie. Popyt na tego typu rozwiązania 
wzrasta, gdyż potwierdza się ich skuteczność w procesach edukacyjnych. Pozwalają one m.in. na szybką ewaluację podejmowanych działań, na śledzenie i szybką analizę postępów. Nie wymagają czasochłonnej archiwizacji działań. Pozwalają uczącym się i nauczającym przeznaczać większą ilość czasu na działania niestandardowe, a więc twórcze i kreatywne.

Nowa gospodarka to zatem wyzwania nie tylko dla rynku pracy, ale przede wszystkim dla systemu edukacji. Zmieniające się dynamicznie otoczenie wymaga nowych kompetencji, a więc dostosowania programów edukacyjnych do nowych realiów technologicznych i społeczno-gospodarczych Wyposażenie uczniów w kompetencje, które pozwolą im jak najlepiej odnaleźć się w nowym otoczeniu, powinno stanowić wyznacznik dla opracowywanych programów kształcenia. Kluczowym wyzwaniem polityki naukowej i gospodarczej jest zapewnienie, by podaż i popyt na nowe umiejętności i kompetencje były jak najbardziej dopasowane. Według Komisji Europejskiej (Learning and Skills...) to nauka odpowiednich umiejętności jest kluczowym czynnikiem wpływającym na rozwój społeczeństwa i gospodarki. To ona ma zagwarantować obywatelom możliwość znalezienia zatrudnienia i aktywne uczestnictwo w życiu społecznym. 